\title{
ПРАКТИКА ПРАВОВОВОГО РЕГУЛЮВАННЯ КИТАЙСЬКОЮ НАРОДНОЮ РЕСПУБЛІКОЮ ГЛОБАЛЬНИХ ЛАНЦЮГІВ ДОБАВЛЕНОӤ ВАРТОСТІ
}

\author{
БАРАНОВСЬКА Віра Миколаївна - кандидат юридичних наук, доцент \\ кафедри господарського та цивільного права Навчально-наукового інституту \\ права ім. Володимира Великого Міжрегіональної академії управління персоналом \\ ORCID ID: https:0000-0003-2784-0416 \\ ДИКАРСВ Олександр Іванович - кандидат політичних наук, доцент \\ кафедри міжнародних відносин КНУКІМ \\ ORCID ID: https: 0000-0002-1895-0878 \\ УДК: $327+339+347$ \\ DOI 10.32782/NP.2021.3.24
}

У статті концептуалізується актуальний для Украӥни китайсъкий досвід стратагеювання : (1) прямим іноземним інвестуванням (далі - ПII) у контексті глобалізациї, коли значення має не кінцевий продукт, як об'єкт міжнародної торгівлі, а результат діяльності бірми в процесі створення изього продукту; (2) геофінансами як сукупністю економічних відносин, пов'язаних з формуванням, розподілом, перерозподілом начіонального та світового доходу на основі бінансово-кредитних, інбормаиійних та інших операиій окремих країн, регіональних інтеграційних спілок, Геобінанси розглядаються як сукупність економічних відносин, пов'язаних з бормуванням, розподілом, перерозподілом $i$ використанням наиіонального та світового доходу на основі бінансовокредитних, інбормаційних та інших операчій окремих країн, регіональних інтеграчійних спілок та глобальних акторів у русі дестафірованних грошових фондів. Концептуалізується, що: (1) участь у глобальних мережах добавленої вартості (далі - ГМДВ) сприяє інвестуванню в розвинуті, та такі, щзо розвиваються, краӥни незалежно від їх рівня технологічного розвитку та доходів на душу населення; (2) ГМДВ виступає механізмом нарахування вартості в прочесі створення кінцевого продукту, що включає в себе технологічні стадї виробниизтва, дизайн, збут; (3) сприятливий інвестиизйний клімат означає економічно привабливі умови ведення бізнесу (помірні податки, пільги, гарантії), політичну стійкість, фбінансові умови, що впливають на приплив внутрішніх і зовнішніх інвестииій в економіку крайн, наявність законодавчої бази; (4) ПІІ виступають як різновидність капіталовкладень у підприємство, галузі економіки краӥни (міжнародний рух капіталу в бормах: 1) інвестування безпосереднъо в підприємство, землю та інші капітальні об'єкти; 2) як управлінсъкий контроль над об'єктом інвестування; 3) горизонтальні (коли господарюючий суб’єкт з краӥни-донара отримує чи вкладає в компанію того ж рівня та типу в технологічному ланиюзі в країні-рецепієнті з метою нарощення потужностей; 4) вертикальні (коли господарюючий суб'єкт з краӥни-донора вкладає в фірму 3 нижчим чи вищим рівнем у технологічному ланщюзі в краіні-рецепіснті)).(5) Стратегіювання - иее геополітичні, геоекономічні, геофіеансові стратегій 3 китайською специбікою, що забезпечують інтереси інвестора-донара та держави, у забезпеченні впливу на поведінку підприємста-реципієнта (6) звернення до досвіду КНР викликане рядом обставин: 1) значення участі в ГМДВ особливо важливо для країн, що розвиваються; 2) Китай иілеспрямовано включає галузі економіки в ГМДВ; 3) саме Китаю в геобінансовій архітектурі відводиться ключова роль, яка визначається зростанням його економічного потениіалу; 4) у КНР накопичився значний досвід розробки правових механізмів регулювання ПІІ в умовах участі в ГМДВ.

Ключові слова: іноземне інвестування, КНР, добавлена вартість, ланиюги, геобінанси, господарюючий суб'єкт. 
У цій статті актуалізуються теоретична рефлексія регулювання фінансових потоків у ГМДВ та специфіка цього процесу в Китаї, визначену в тріаді стратагем: (1) «приховуйте свій блиск, будьте терплячі, завжди є чим зайнятися» (Ден Сяопін) - (2) «у світі, де всі речі «вміщуються одна в одну», не може бути репрезентації, оскільки у ньому реальність не виражається, а саме «виписується» візерунками життєвих метаморф (Чжуан-цзи) - (3) «споглядайте Піднебесну від Піднебесної» (Лао-цзи). Автор звертається до теоретичних рефлексій ряду вчених, а саме таких: С.С. Алексєєв, ІІ. Голдфінгер (Goldfinger Ch.), Гішар Жан-Поль та Брюне Антуан $\mathcal{\lambda}$., Брукс (Leonard Brookes), Г. Сандерсон (Gary Sanders), M. Гановеттер (M.Granovetter), E.C. Купер (Cooper A.S.), II. Стефенсон (Sherry Stephenson), B. Катасонов, Т.Чирков, М.В.Яковлєв.

Автор стоїть на підході дослідникаIII. Голдфінгера до геофінансів як фінансового простору-часу, що ігнорує закони географії та національні кордони, синтез світових грошей, інформаційних технологій та лібералізації законодавчого регулювання [17]. Дослідники позиціонують ряд особливостей геофінансових систем: 1) геофінанси, що склалася до початку глобальної кризи, за своїми масштабами і механізмами функціонування стали результатом попереднього етапу глобалізації;2) важливою характеристикою геофінансів став їх розвиток за власними законами, що спричинило відрив від національних фінансових систем; 3) часткове переміщення функцій регулювання відносин до світових фінансових центрів, головним критерієм економічної діяльності яких є максимальна прибутковість $[5 ; 7 ; 14 ; 16 ; 19]$. Важливою для цього дослідження стали результати вчених Гішара Ж.-П. та Брюне А. по дослідженню геополітичних та геоекономічних стратегії лідерства. Вони ставлять під сумнів концепцію «обмін завжди краще автаркії»: «Класичні автори... навіть автори-кейнсіанці не приділяють достатньо увагу тому факту, що країну можливо довести до бідності в процесі інтеграції у світову торгівлю» [3,С. 49]. Далі вчені стверджують, що «як мінімум чотири століття підтверджується справедливість меркантилістської тези: спостерігається постійна тенденція в проведенні меркантилістської політики певними пануючими країнами, чи країнами, що прагнуть лідерства, що основується на стійкому торговому профіциті» [3,С. 50]. Усі ці ідеї до певної міри є справедливими. Проте основною думкою цих авторів у книзі «Геополітика меркантилізму» виступає не проблема «накопичення боргів» чи, по іншому, валютно-фінансової експансії, а швидше їх стурбованість та еліти Заходу в цілому можливістю втратити це лідерство. I таким чином позбавитися можливості продовження нарощувати борги перед периферією. Ці вчені вважають, що захисною реакцією стало формування у світовому господарстві нової форми інтернаціональної збалансованості, у рамках якої світовий баланс експорту й імпорту продукції врівноважується світовим балансом вивозу та ввозу капіталу. Таким чином, відбувається формування геофінансових стратегій координації інтернаціональних грошово-кредитних та фінансових відносин, направлене формування динаміка валютних курсів [3,C.109]. Така практика на початку XXI ст. продемонструвала свою неадекватність потребам соціуму. Факт фінансової кризи на Кіпру вперше продемонстрував сценарій вирішення проблем, що виникли через прорахунки фінансових інститутів i ï регуляторів, за рахунок банківських вкладників. Іншою новиною такого плану є заява Китаю про те, що нагромадження іноземної валюти більш не відповідає інтересам КНР. Наступним очікуваним кроком з боку КНР є перехід Шанхайської ф'ючерсної біржі (Shanghai Futures Exchange - SHFE) на оцінку всіх контрактів на сиру нафту в юанях.

Виходячи з цих фактів, автор цієї статті ставить за мету: 1) аналіз правового регулювання сучасної конкурентної боротьби на світових ринках та специфіки ПІІІ в умовах участі в ГМДВ; 2) дослідити сучасні китайські стратегій регулювання міжнародних фінансових відносин у контексті побудови власних ГМДВ в Африці, 


\section{Міжнародне право}

Латинській Америці, на Близькому Сході; 4) на прикладі КНР розглянути планове будівництво системи фінансового законодавства.

На початку необхідно зауважити, що практика КНР аналізується з урахуванням давньої традиції законодавчого регулювання соціальних відносин. Тут важливим дороговказом для дослідника послугувала концепція дослідника С.С. Алексєєва про те, що «в межах традиційних цивілізацій, переважно східних, де домінувало невіддеференційоване право, нерідко виділяли коло відносин, що по логіці суспільного життя приводить до затвердження в цьому «колі» безпосередньо юридичного, законодавчого регулювання. Так, у Китаї навіть після втрати впливу «школи легістів», при династії Хань (226 р. до н.е.) й у наступні століття, коли панували ідеї конфуціанства, було вже визнано, що питання адміністративного та карного права є підвладними закону, і це виразилося у виданні серії кодексів, що вирізнялися високою юридичною технікою. Дія кодексів безпосередньо забезпечувало владу зі своїм каральним апаратом» [1,С.140]. Традицією для Китаю є бачення світу в геометрично осмислених схемах. Геополітика та дипломатія традиційного Китаю мала вигляд феншую, тобто осмисленого в термінах геоманітії та краси феномену. Феншуйна схема, яка стала лише продовженням магічної практики і якою можна керувати саме через чіткий геометричний розрахунок та стратагемність, була закладена в політичну традицію управління світом. Розвиток традицій та стратегем воєнного мистецтва в Китаї пов'язують 3 напівлегендарною особою Сунь Цзи (Сунь У) та 3 ім'ям історичного діяча Сунь Біня. Сунь Бінь залишивши службу в армії, присвятив себе написанню книги «Мистецтво війни Сунь Біня» і навчанню стратагемновійськовому мистецтву своїх обраних послідовників. У своїй книзі великий стратег звів докупи власні розробки в галузі військової майстерності, які стали важливим доповненням «Мистецтва війни» Сунь Цзи для досягнення влади через створення загроз: політичних, економічних, торгівель- них. Нині в КНР продовжену цю традицію i напрацьовано тріаду тріадних концепцій: І. Глобальні концепції стратагеювання світом: (1) «Новий шовковий шлях»: побудова трансконтинентальних мереж у Евразії - «економічний пояс Шовкового шляху» і морський Шовковий шлях у Південній Азії» для просування товарів на Захід» - (2) «Перлинове намисто»: ця «нитка перлів» складається з баз і дипломатичних зв'язків і вибудовують стратегічні мережі вздовж морських транспортних коридорів від Близького Сходу до Південно-Китайського моря»- (3) «Одвічний єдиний багатонаціональний Китай»: народи, які коли-небудь входили в межі імперії, платили данину, або посилали послів, або навіть завоювали Китай автоматично вважаються китайцями»; II. Геоекономічні концепції: (1) «створення зони Азійсько процвітання: підтримка країн Азї̈ - (2) «вільний доступ до ринків збуту та енергетичних ресурсів: інвестування країн Африки, Аатиської Америки в обмін на ресурси» - (3) «забезпечення конкурентоспроможності експорту та прив'язка економік інших країн держав до своєї економіки»; III. Геополітичні концепції: (1) «ослаблення позицій США в Східній та Південній Азї̈ - (2) «дипломатичне позиціонування КНР центром інтеграції в Східній Азії та стратагеювання в рамках форуму АСЕАН + Китай та інших багатосторонніх форматах Південно-Східної Азії та АТР» - (3) «збереження «свободи маневру» в регіональних і глобальних міжнародних організаціях і недопущення втягування в міжнародну війну з тероризмом» [4]. Вищевикладене свідчить про те, що важливим фактом для дослідження виступає прагнення еліти КНР активно сприяти розвитку всіх рівнів ГМДВ і нарощувати розміри прямих та непрямих капіталовкладень у глобальні енергетичні потужності і виробництво продукції у сполучених галузях. Синолог В. Малявін стверджує, що формули китайської політики: «стратегічне партнерство», «громадська гармонія», «єдність у багатополярності» направлені на контроль над інфраструктурою, мережею для забезпечення стратегічної переваги у взаємодії всіх рівнів. Ці 
поняття цілком стратагемні, тобто свідомо беззмістовні, мінливі і співвідносяться насправді не з предметами чи поняттями, а 3 конкретністю практики [11]. Аналізуючи результати здійснення цих планів Гішар Ж.-П., Брюне А. причиною сучасної глобальної кризи називають саме спроби Китаю стратагіювання західними компаніями, імпорт з геополітичною метою, побудова «першокласної» військової машини... поширення у світі позитивних уявлень про «моделі» розвитку Китаю» [3,С. 150]. Проте, на нашу думку, така логіка Гіша-ра Ж.-П., Брюне А. підводить до неоднозначного висновку про те, що провина КНР полягає в тому, що там змогли: 1) створити умови для притоку інвестицій; 2) не піддатися тиску ТНК; 3) продовжити адекватну для етнокультурної традиції стратегію розвитку. Крім того, як зауважуе дослідник Дж. Арригі, ще А. Сміт вважав самостійний шлях розвитку Китаю позитивним явищем у порівнянні 3 «неприродною й реакційною» економікою Европи. У кінці XVIII ст. Китай був світовим економічним лідером, який виробляв третину валового продукту світу, відстоював недоторканість внутрішнього ринку, підтримував достатній рівень життя більшості населення. Тільки в результаті двох опіумних війн Захід спромігся відкрити для своїх товарів китайський ринок. Хоча, на думку Арригі, А. Сміт - один 3 незрозумілих теоретиків, і тому з ним пов'язано ряд міфів. Зокрема, що А.Сміт є: 1) прибічником «саморегулюючих ринків»; 2) прибічник капіталізму та його «безмежної» економічної експансії; 3) теоретиком такого поділу праці, яке мала місце на шпильковій фабриці, описаній в першому розділі «Багатства народу». Насправді це не так. Щодо розвитку Китаю, Аррагі вважає, що подальші вектори розвитку світу залежать від виживання етики «старанності» під тиском ідеології соціуму споживання [2].

Дослідник М.Гранноватер [19-20], досліджуючи процес появи й розвитку галузей промисловості, зокрема енергетичної в США, робить висновок про роль соціальних мереж: 1) навіть ринкова потреба в розвитку певних галузей економіки та фірмах необов'язково сприяє їх появі, якщо соціальні зв'язки груп інтересів не підтримають таку ідею; 2) динаміка цього процесу в значній мірі залежить від структури зв'язків впливових сімей; 3) формування галузі відбувається в різноманітних формах у залежності від типу міжособистих мереж провідних акторів; 4) еволюція фірм та бізнес-груп відбувається за рахунок зростання паттернів діяльності в міжособистісних мережах стійких економічних інститутів; 5) структура інститутів відображає характеристику мереж і якщо мережі зникають, то інститути «завмирають» і тим самим обмежують трансформацію в нові форми; 6) процеси мережевої фрагментації чи єдності (cohesion), створення чи розриву зв'язків виступають головною детермінантою результатів; 7) успішним актором буде той, хто охоплює своєю мережею найбільшу кількість необхідних інституційних сфер. Таким чином, теоретичне бачення Грановеттера у контексті соціологічної парадигми висуває мережеву теорію концепцією «бізнес-груп» [20, С. 453-475], де «бізнес-групи» створюють «ряд фірм, пов'язаних одна 3 одною формальною та/ чи неформальним чином», та відрізняються від звичайних конгломератів проявом «соціальної солідарності» [20, С.454, 462463]. При цьому точка зору Грановеттера є протилежною «включеності» Поланьї в розумінні економічної дії як соціальної дії, у тому числі й в умовах капіталізму в контексті мереженої теорії.

Певні імпиричні дослідження підтверджують наявність і вплив навіть глобальних мереж. Так, дослідники з Цюриху напрацювали комп'ютерну модель світової економічної та фінансової системи на основі бази Orbis, у якій міститься інформація про 43 тис. ТНК, 37 млн. компаній та інвесторів станом на 2007 р. Було встановлено «ядро» 31318 компаній (20\% прибутку від світового), кожна 3 яких має мережеві контакти 3, у середньому, 20 фірмами. Через систему участі в капіталі вони контролюють 60\% світового ВВП. «Ядро» містить 147 компаній, що контролюють $40 \%$ світових активів, у тому числі $90 \%$ активів у банківській сфері (Мал.1.). Дослідник А. 


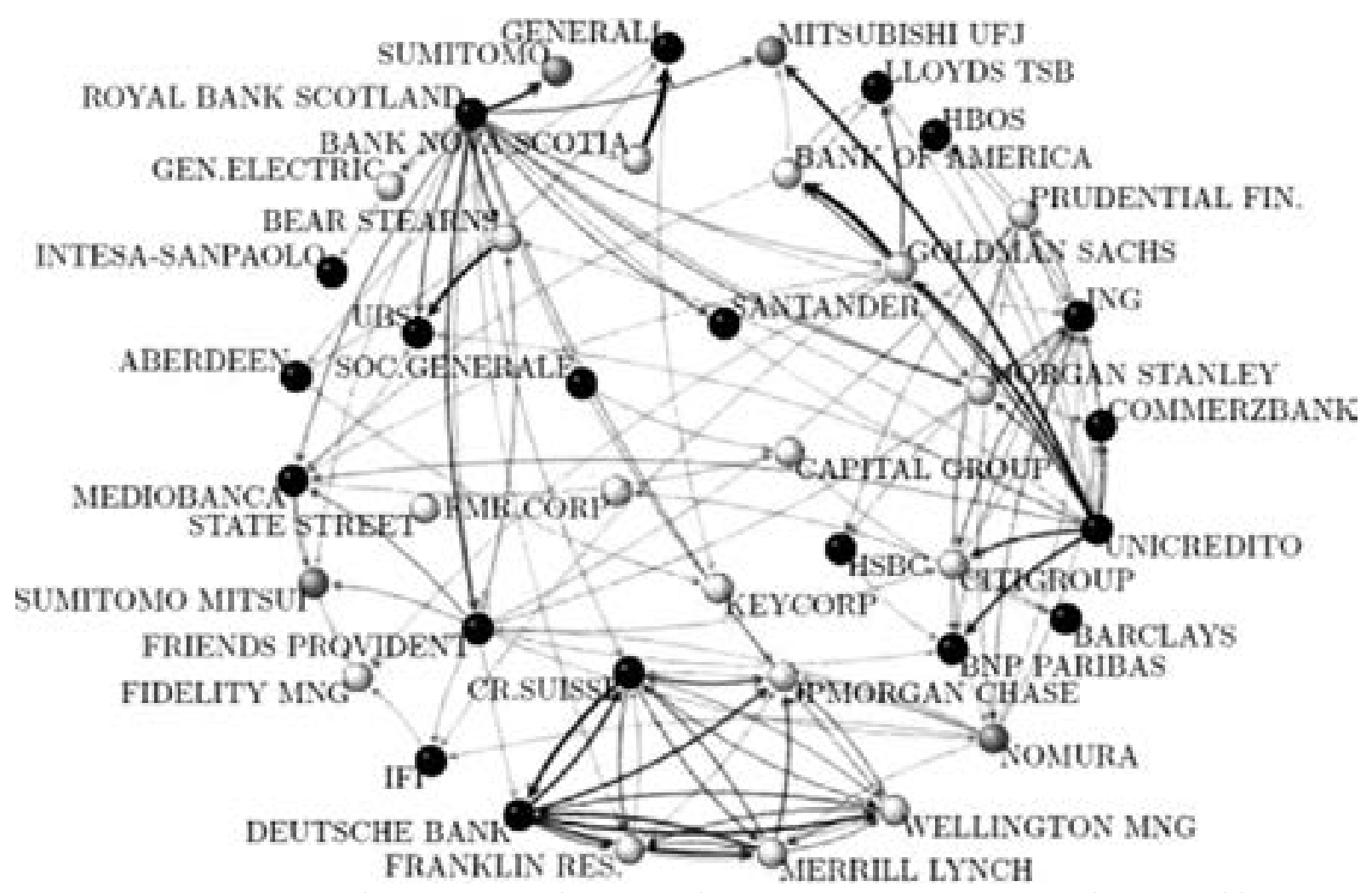

Мал.1. Модель світової економічної та фінансової системи на основі бази Orbis.

(http://rodovid.me/climate_change/kto-upravlyaet-mirom.html)

Костон [7] також свідчить про існування взаємозв'язку фінансових олігархів 3 політичною елітою. Він стверджує, що механізм взаємодії формується з XVI ст.

Аналітик III. Стефенсон [21,C.3], аналізуючи механізми ГМДВ, називає як основні рушійні сили інвестиційні рішення МНК, пов'язані із використанням незалежних підрядних організацій та офшорних операцій. Таким чином, можна стверджувати, що функціонування ГМДВ обумовлено змінами в поведінці компаній й свідчить про зміни в економічній сфеpi соціуму. ШІ. Стефенсон також свідчить про те, що природа ГМДВ $є$ варіативною в наслідках розвитку в залежності від галузі та сектора економіки: ГМДВ переробка природних ресурсів відрізняються від промислових. Однак послуги складають обов'язків елемент для всіх ГМДВ. Таким чином, надання послуг дає можливість доступу до ГМДВ усім країнам незалежно від забезпеченості ресурсами, оскільки отримання завдання на послуги залежить в основному від рівня навичок, освіти й підготовки працівників, а також від політико-правового середовища маркетингу. Уряди можуть впливати на всі ці фактори $[21$, C.7]. При цьому нині торгівельна політика не виступає універсальним рішенням і виступає лише частиною набору механізмів: вона може допомогти лише в деяких процесах, пов'язаних з ВТО [9;11;16;22]. Нині китайська промисловість продовжує

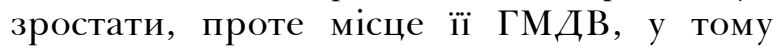
числі енергетичних, буде плавно змінюватися. Такий фактор зростання як дешева робоча сила, вичерпала себе, оскільки в 2014 р. середня зарплата складала 725 дол. Крім того, КНР активно виходить на зовнішні ринки. В останній час у КНР щодо цієї політики було прийнято ряд документів: «Стратегія Китаю щодо країн Африки» (2006 р.); «Стратегія Китаю щодо країн Аатинської Америки і Карибського басейну» (2008р.). Китайську специфіку стратагеювання склали відносини 3 країнами Близького Сходу. Факт зростання рівня політичних ризиків у цьому регіоні стимулював пошук неформальних, не за- 
кріплених на законодавчому рівні стратегій. Хоча зберігаються тісні відносини 3 акторами цього регіону вже протягом 20-30 років. Було створено Форум китайсько-арабської співпраці. Нині діє досить багаторівнева система двостороннього i багатостороннього діалогу на різних державних рівнях, а також приватного бізнесу. Тут стратегія спирається на «китайську церемонію», тобто на ідеал поступливості, «залишення себе», що вивільняє потенціал перетворень і, відповідно, простір для стратегічних маневрів. У «великій грі» китайської стратегії перемагає той, хто більше поступається. Уже згадуваний даоський філософ Чжуан-цзи трохи переінакшив формулу Лао-цзи, сказавши, що душевний спокій знайде той, хто зуміє «заховати Піднебесну в Піднебесній». Порада настільки ж серйозна, як і жартівлива, адже пропонується знайти все, залишивши все. На відміну від західних філософів, які шукали точку опори, яка дозволить перевернути світ, китайська стратагема пропонує залишити світ у спокої, щоб дозволити здійснюватися всім його перетворенням. Перші, по суті, знищують світ, другі вивільняють невичерпну різноманітність світу [9-14]. Африка виступає другим за величиною джерелом імпорту Китаю сирої нафти після Близького Сходу, частка в експорті нафти якого становить близько 52\%. У 2014 р. Китай імпортував з Африки близько 1,3 млн. барелів на день, або $23 \%$ від загального обсягу імпорту. Серед найбільших постачальників нафти на Африканському континенті - Ангола, на частку якої припадає $11 \%$ китайського імпорту, Конго - 2\% і Південний Судан - 2\%. Крім нафти, Китай імпортує також залізні руди, метали та інші сировинні товари, а також харчову та сільськогосподарську продукцію. Китай є найбільшим споживачем міді у світі - обсяг його споживання склав $44 \%$ від загального обсягу споживання у світі, а в число його основних джерел входять країни Африки та Росія. У той же час Китай експортує широкий спектр машин i транспортного устаткування, комунікаційного обладнання, електроніки африканським країнам. На прикладі китайських
CE3, в шести зонах Африки були створені зони китайсько-африканського економічного співробітництва. У кожній із зон базуються більше десятка китайських підприємств, у яких працюють як китайські, так і африканські співробітники. У 2007 р. відбулося відкриття першої зони в Чамбіші в Замбії. ПІІ КНР в Африку в 2013-2014 рр. склали 4,4\% від загального обсягу ПІІ на континенті [5;18;13].

Ще в 1998 р. КНР і країни, що входять у загальний ринок Південної Америки, напрацювали Програму довгострокового співробітництва, що передбачала: а) поступову взаємну лібералізацію торгівлі товарами та послугами; б) розвиток спільного підприємництва; в) створення додаткових стимулів для співпраці в науково-технічній сфері. Пекін пропонував укласти угоду про вільну торгівлю, однак керівники ряду держав регіону ще не дали своєї згоди. Існує певний ризик напливу дешевих товарів, що користуються попитом у малозабезпечених верств населення, що може спричинити кризу в місцевій шкіряній, швейній і текстильній галузях економіки. Внаслідок цього частка легкої промисловості у валовому внутрішньому продукті, наприклад, Бразилії зменшилася з $16 \%$ до $13 \%$, а Колумбії - на 4\%. Тут, як і в Африці, стратегія Китаю, згідно 3 оцінками ряду експертів, зводиться до реалізації так званої «африканської моделі». Ї̈̈ суть в узагальненому і спрощеному вигляді виражена у формулі: «ви нам сировину, ми вам готові вироби». Звідси у латиноамериканської еліти виникає побоювання перетворення своїх країн у сировинні придатки КНР. У КНР сратагіюють здатністю країни стимулювати розвиток ГМДВ, що сприяє економічній інтеграції, однак вигоду отримує та сторона, яка зможе підняти величину отриманої добавленої вартості.У КНР більша частка, а саме $86 \%$ кінцевого споживання промислових товарів та ринку послуг складає додаткова вартість отримана в середині країни. Частка добавленої вартості іноземних компаній отримана за межами країни, склала 14\%. Нині економічний розвиток КНР перейшло в стадію «нової норми», тобто сповільнення темпів 


\section{Міжнародне право}

економічного зростання на користь тріаді ефекту: (1) «якість розвитку»-(2) планове «збалансування» секторів економічної - (3) «застосування нових технологій». Особливістю китайської економіки лишається той факт, що уряд використовує п'ятирічні плани для здіснення національної стратегії розвитку. Після реформи 1978 р. провідною метою стали не кількісні показники випуску продукції, заходи по відкриттю ринків та залученню інвестицій. Швидке економічне зростання забезпечило Китаю одне 3 провідних місць серед провідних виробників [9-14;16].

Дослідниця А.Ю Урюпіна стверджує, за останні роки відбулася трансформація ПІІ з боку ТНК в КНР: 1) зросла частка інновацій та технологій, що передаються підприємствам за участю іноземного капіталу; 2) розширено мережі науково-дослідних центрів на території Китаю; 3) перепідготовлено національні кадри КНР;4) зростають капіталовкладення у високотехнологічні, а не трудомісткі галузі в Китаї; 5) якщо раніше технології ТНК випереджали китайські на 10-15 років і використовувалися рідко з огляду на технологічний розрив, то з 2001 р. число підприємств, які використовують найпередовіші технології «материнської» компанії складає вже 40\% [14].

У значній мірі цьому сприяли заходи по введенню нового правового механізму управління та адміністрування в КНР. А саме: (1) у 1993 р. на восьмому скликані ВСНП були прийняті зміни до положення про "Державне використання соціалістичної ринкової економіки». А саме, було введено поняття «суспільна власність», що базувалася на соціалістичній плановій економіці». Тобто законодавчо було закріплено принципи регулювання ринкових відносин. Поправка до Конституції визначає, що «Держава укріпляє економічне законодавство й розвиває макрорегулювання»; (2) у період 1993-1998 рр. було прийнято 85 законів та 33 рішення, які склали базу вже з 118 законів, що мали регулювати ринкові відносини; (3) у 1999 р. на другій сесії дев'ятого скликання ВСНП була прийнято закон про договори; було напрацьовано: корпоративний закон; підприємницький закон; на законодавчому рівні були встановлені правила поведінки на ринку з метою недопущення нечесної конкуренції: закон про захист прав споживача, закон про якість продукції, закон про користування міською нерухомістю, закон про рекламну діяльність, закон про аукціони, закон про векселі, закон про страхування, зобов'язальне право, закон про арбітраж; правила мікрорегулювання економіки: бюджетне право, закон про управління Народним банком Китаю, закон про аудит, закон про ціни; для регулювання відносин суб'єктів базового виробництва та індустрії було прийнято закон про сільське господарство, закон про електроенергію, закон про вугілля; 4) в 2007 р. на 29 сесії десятого Національного Народного Конгресу було створено «Економічне законодавство»: як доповнення до закону про договори та антимонопольне законодавство КНР було напрацьовано закон про власність, закон про державну власність, закон про прибутковий податок 3 підприємств, закон про контроль банківської справи, закон про цінні папери, закон про інвестування. Для регулювання адаптації підприємств до ринкових умов були прийняті поправки в закон про товарні знаки, закон про рекламу, закон про сумотні підприємства, закон про підприємства із іноземним капіталом, закон про сумісні підприємства, закон про якість продукції, закон про сільське господарство[15]. У 2010 р. КНР вийшов на друге місце по економічному розвитку. Об'єм валютних коштів у 2014 р. у китайській економіці досягли суми в 10 трлн. дол. Заплановано, що в період до 2020 р. у КНР буде побудовано суспільство середнього достатку [9-11].

у суспільному житті всеєдність перетворень відповідає тому, що в Китаї називали «серцем» або «сподіванням народу», вона ж людська спільність, глибина людства в кожній людині: реальність начебто смутна, але внутрішньо безсумнівна. Тверда віра в таку споконвічну свідомість життя складає одну з найбільш примітних особливостей суспільної свідомості китайців. Сучасні китайські політологи часто 
апелюють до нього, критикуючи демократичні інститути Заходу. Але їх погляд не так уже й далекий від уявлень про демократію в сучасній Европі, де поняття громадськості, народу і самої влади вже трактуються як щось відсутне в собі [10:13]. Діяльність інвесторів в Китаї регулюється такими основними законодавчими актами, як Законом КНР «Про спільні підприємства 3 китайським і іноземним капіталом», Законом КНР «Про підприємствах 3 іноземним капіталом». Найважливішим етапом формування правового механізму стала фінансова реформа в КНР, оголошена Державним радою в 1993 р. «Рішенням про фінансову реформу». Були здійснені реформи державних спеціалізованих банків, диверсифікованих фінансових інститутів. У 2013 р. відбувся Третій пленум ЦК КПК 18 скликання, який висунув «рішення по ряду основних питань, що стосуються всебічного поглиблення реформ». Було виділено тріадну стратагему фінансової реформи Китаю: (1) «фінансовий сектор повинен знову почати приносити користь реальній економіці (фінансовий сектор було виділено із загального сектора послуг» - (2) «віртуальна економіка створює парний термін $з$ реальною економікою (поява терміна віртуальної економіки підкреслює важливість фінансування, але, 3 іншого боку, робить більш явним зняття перепон між фінансовим і реальним секторами економіки)» - (3) звернення до фінансової системи Пратта і Вітні, згідно 3 якою «всі учасники ринку могли 6 ділити між собою благодатний дощ системи фінансових послуг» (відсилання фінансової реформи до регулювання ринку за умови доступності до фінансової системи багатих і бідних)» [6]. 3 поступовою відмовою від втручання центрахьного банку на валютному ринку була сформована тенденція реверсивного коливається курсу китайського юаня, а також вдосконалено самостійний балансуючий механізм і здатність відновлення валютного ринку [5;8-13]. Інвестиції п'ятисот найбільших ТНК у такі галузі, як електроніка, телекомунікація, транспорт і зв'язок, хімічні матеріали і продукти складають $55 \%$ від загальної суми інвестицій у Китаї. Великі міжнародні компанії не схильні вкладати кошти у виробництво тканин, одягу і в інші галузі, що вимагають використання більшої кількості робочої сили. Інвестиції ТНК у подібні галузі становлять лише $2 \%$ від загальних вкладень у Китай [10-13].

Отже, у структурному плані геофінанси - це глобальна мережа традиційних і віртуальних, дематеріалізованних (дестафірованих) фінансових ринків, що функціонують на них, учасників, при організуючій i провідній ролі інтермедіаторов (посередників) і можуть виступати у формі ГМДС. Чжуан-цзи, закликаючи «заховати Піднебесну в Піднебесній», свідчив про глибоку правду китайського світу. Ця правда, як ми переконалися, визначила форми глобальної експансії Китаю в сучасному світі: прагнення не вести за собою, а самому бути веденим верховною силою; співпраця та ії користь важливіша формальних цілей та ідеологічних постулатів. Це прагнення Китаю «приховувати свій блиск» проявляє себе в дуже багатьох рисах китайської ділової культури, починаючи 3 любові до імітацій іноземних брендів, готовністю задовольнитися роллю постачальника деталей для західної продукції, створення складних мереж виробничих, фінансових i торгових підприємств; бізнес - явище у великій мірі колективне, його живильне середовище - квазіродинні, підкреслено особистісне спілкування.

\section{Мiтература}

1.Алексеев С.С. Собрание сочинений. В 10 т. [+ Справоч. том]. Том 6: Восхождение к праву. - М.: Статут, 2010. - 558 с

2.Арриги Дж. Адам Смит в В Пекине: что получил в наследство XXI ВЕК/ Пер. С англ. Т.Б. Менская. - М.: Институт общественного проектирования, 2009. $456 \mathrm{C}$.

3.Брюне Антуан. Геополитика меркантилизма: новый взгляд на мировую экономику и международные отношения: пер. с фр. / Гишар Жан-Поль, Брюне Антуан. - М.: Новый хронограф, 2012. - 232 с. : ил. - (Серия «Социальное пространство»). 


\section{Міжнародне право}

4.Дікарієв О.І. Стратегії ресурсної дипломатії в рамках чотирикутника: Сплучені Штати Америки - Російська Федерація - Китай - Свропейський Союз / O.I. Дікарієв, О.П. Степанов. Монографія. - Юрисконсульт, 204. - 304 с.

5.Экономическая реформа в КНР: на рубеже веков / Сост.: П.Б.Каменнов. М.: Институт Дальнего Востока РАН, 2008. 288 c.

6.Инь Чжәньтао. Три основных направления финансовой реформы Китая // Сборник научных трудов по итогам конференции молодых ученых Академии общественных наук КНР и СанктПетербургского государственного экономического университета / под ред. проректора по научной работе СПбГЭУ, д-ра экон. наук проф. А.Е. Карлика. СПб.: Изд-во СПбГӘУ, 2016. - С. 74-86.

7. Костон Анри. Финансисты, которые управляют миром / Анри Костон. - М.: КМК 2007. - 296 с. - (Серия: Мир. Хаос. Порядок).

8.Аубская Е.В. Мировые тенденции развития глобальных цепочек добавленной стоимости: место Китая /Е.В. Аубская / Сборник научных трудов по итогам конференции молодых ученых Академии общественных наук КНР и Санкт-Петербургского государственного экономического университета / под ред. проректора по научной работе СПбГЭУ, д-ра экон. наук проф. А.Е. Карлика. СПб.: Изд-во СПбГЭУ, 2016. - С. 204-211.

9. Ауцишин 3.О. Асиметрія та парадокс фінансової глобалізації / Зоряна Ауцишин // Міжнародна економічна політика. - 2008. - № 1-2 (8-9). - С. 88 - 121

10.Аю Чжаньли. Анализ факторов привлечения иностранных инвестиций в настоящее время / Лю Чжаньли, Кэчжань Дин // Актуальные проблемы современной науки . - 2003. - 05 - N3 . - C.36-41

11.Малафеев А. А. Глобальные цепочки создания стоимости в развивающихся странах // Научное сообщество студентов XXI столетия. Экономические науки: сб. ст. по мат. XLIV междунар. студ. науч.практ. конф. - Електронне джерело. - Матеріал знаходиться на сайті: URL: http:// sibac.info/archive/economy/7(44).pdf (дата звернення: 27.11.2016)

12. Малявин Владимир. О глобальной стратегии Китая. - Електронне джерело. Матеріал знаходиться на сайті: 29.04.2016 http:// trends.skolkovo.ru/ 2016/04/ vladimirmalyavin-o-globalnoy-strategii-kitaya/

13.Морозов М.А. Современные факторы инвестиционной привлекательности Китая / Сборник научных трудов по итогам конференции молодых ученых Академии общественных наук КНР и Санкт-Петербургского государственного экономического университета / под ред. проректора по научной работе СПбГӘУ, д-ра экон. наук проф. А.Е. Карлика. СПб.: Изд-во СПбГЭУ, 2016. - С. 211-218.

14.Урюпина А.Ю. Тенденции в мировом экспорте и импорте прямых зарубежных инвестиций / А.Ю. Урюпина // Вопросы экономических наук. - 2007. -№ 3. - С. 169-173

15. Чжэнь Фэн. Законодательство и его влияние на экономическое развитие Китая / Сборник научных трудов по итогам конференции молодых ученых Академии общественных наук КНР и Санкт-Петербургского государственного экономического университета / под ред. проректора по научной работе СПбГӘУ, д-ра экон. наук проф. А.Е. Карлика. СПб.: Изд-во СПбГЭУ, 2016. - С.86-83.

16.Экономическая стратегия КНР в XXI в. и вопросы сотрудничества с Россией /сост. П.Б. Каменнов; отв. ред. И.Н. Наумов. - М.: ИДВ РАН, 2009. - 330 с.

17.Baldwin Richard. Stephenson S Global Value Chains: The New Reality of International Trade / Sherry Stephenson. Switzerland: International Centre for Trade and Sustainable Development (ICTSD), 2013.- 12 p.

18.Goldfinger Ch. Innovation in Financial Services // Communications \& Strategies,No. 48, 4-th quarter 2002. Pp. 139-160.

19.Granovetter M. Economic Institutions as Social Constructions: A Framework for Analysis // Acta Sociologica. - 1992. - №35. P. 3-11.

20.Granovetter M. Business Groups // The Handbook of Economic Sociology / N. Smels- 
er, R. Swedberg (eds.). Princeton: Princeton University Press, 1994. - P. 453-475Stiglitz JE. Freefall: America, free markets and the sinking of the world economy. - N.Y., London: W.W. Norton \& Company, 2010. - 361 p.

21.Stephenson S Global Value Chains:

The New Reality of International Trade /

Sherry Stephenson. Switzerland: International Centre for Trade and Sustainable Development (ICTSD), 2013.- 12 p.

22.The United Nations Conference on Trade: in today's world a few dozen corporations rule the world, and it is good [Electronic resource]. URL: http://www. finmarket.ru/economics/article/3244103 (date of viewing: 01.06.2015)

\section{SUMMARY}

The article conceptualizes the current Chinese experience of strategizing in Ukraine: (1) foreign direct investment (hereinafter - FDI) in the context of globalization, when the value is not the final product as an object of international trade, and the result of the firm in creating this product; (2) geofinance as a set of economic relations related to the formation, distribution, redistribution of national and world income on the basis of financial and credit, information and other operations of individual countries, regional integration unions, Geofinance is considered as a set of economic relations related to formation, distribution, redistribution and use of national and world income on the basis of financial and credit, information and other operations of individual countries, regional integration unions and global actors in the movement of destabilized funds. It is conceptualized that: (1) participation in global value-added networks (hereinafter referred to as GVANs) promotes investment in developed and developing countries, regardless of their level of technological development and per capita income; (2) GVANs acts as a mechanism for calculating the cost in the process of creating the final product, which includes the technological stages of production, design, marketing; (3) favorable investment climate means economically attractive business conditions (moderate taxes, benefits, guarantees), political stability, financial conditions that affect the inflow of domestic and foreign investment in the economy, the availability of legislation; (4) FDI act as a kind of investment in the enterprise, the country's economy in the form of: 1) investment directly in the enterprise, land and other capital objects; 2) as management control over the investment object; 3) horizontal (when an economic entity from a donor country receives or invests in a company of the same level and type in the technological chain in the recipient country in order to increase capacity; 4) vertical (when an economic entity from a donor country invests in a firm with a lower or higher level in the technological chain in the recipient country)). 6) recourse to the experience of China is caused by a number of circumstances: 1) the importance of participation in the GVANs is especially important for developing countries; 2) China purposefully includes sectors of the economy in the GVANs; 3) it is China that plays a key role in geofinancial architecture, which is determined by the growth of its economic potential; 4) China has accumulated considerable experience in developing legal mechanisms for regulating FDI in terms of participation in the GVANs.

Keywords: foreign investment, China, value added, chains, geofinance, business entity. 